\title{
Effect of Inhibitors of Nucleic Acid and Protein Synthesis on Light-induced Synchronous Conidiation in Botrytis cinerea
}

\author{
By K. K. TA N* \\ Department of Botany, University College, Dublin 4, Ireland
}

(Received 10 June 1977)

\begin{abstract}
The effect of 5-fluoro-2-deoxyuridine (FdUrd), 6-azauridine, miracil D, 5-fluorouracil, cycloheximide, actinomycin D and puromycin on light-induced synchronous conidiation in Botrytis cinerea Pers. ex Fr. is described. FdUrd, 6-azauridine, miracil D, 5-fluorouracil, and cycloheximide inhibited photoinduced conidiation at the appropriate concentrations. Suppression of conidiation was greater when these inhibitors were added just before, rather than after, the photoinduction period. Actinomycin $\mathrm{D}$ and puromycin, both at $10^{-4}$ to $10^{-6} \mathrm{M}$, were ineffective. Incorporation of labelled precursors into nucleic acids and protein in the presence of FdUrd, miracil D, 5-fluorouracil and cycloheximide was greatly suppressed. The results suggest the involvement of nucleic acids and proteins in light-induced conidiation in $B$. cinerea.
\end{abstract}

\section{INTRODUCTION}

Light plays a very important role in the development of many fungal species (Carlile, 1965, 1970; Leach, I97I). How light acts to effect the observed response is still not clear. Studies using inhibitors have shown that RNA synthesis is required during light-induced conidiation in Trichoderma viride (Gressel \& Galun, 1967) and Neurospora crassa (Totten \& Howe, I 97I), and during light-induced carotenogenesis in Verticillium agaricinum (Mummery \& Valadon, 1973). In Aspergillus ornatus, however, Stallings (1970) showed that inhibitors of RNA did not specifically affect light-induced conidiation. The requirement for protein synthesis was suggested by the results of Urey (197I) and Totten \& Howe (I97I) for lightinduced conidiation in $N$. crassa, and by the results of Rau (1967) and Rau, Lindemann \& Rau-Hund (I968) for carotenogenesis in Fusarium aquaeductum and $N$. crassa, respectively. Protein synthesis, however, was not specifically involved in conidiation of $A$. ornatus. This paper describes the results of studies using various inhibitors of nucleic acid and protein synthesis on light-induced synchronous conidiation in Botrytis cinerea Pers. ex Fr.

\section{METHODS}

Organism. Botrytis cinerea Pers. ex Fr. was the isolate used by Tan \& Epton (1973).

Cultural conditions. The fungus was cultured on filter paper as described by Tan (1976) except that Whatman no. 17 filter paper pads of $6 \mathrm{~cm}$ diam. were used, and these were soaked with $4 \mathrm{ml}$ malt extract/ peptone medium. The cultures were incubated in the dark at $20^{\circ} \mathrm{C}$ for 3 days before irradiation with 'black' light for $12 \mathrm{~h}$. Details of the procedures for incubation and irradiation have been described (Tan, 1976). Cultures were returned to darkness after irradiation, and conidiation was assayed $24 \mathrm{~h}$ after the end of the photoinduction period by counting in a haemocytometer (see Tan, 1976).

Application of inhibitors. At the required time, the filter paper on which the fungus was grown was lifted, blotted dry, and placed on a fresh filter paper pad $(7 \mathrm{~cm}$ diam.) soaked with $5 \mathrm{ml}$ medium containing the

* Present address: Department of Biochemistry, University of Singapore, Singapore 3. 


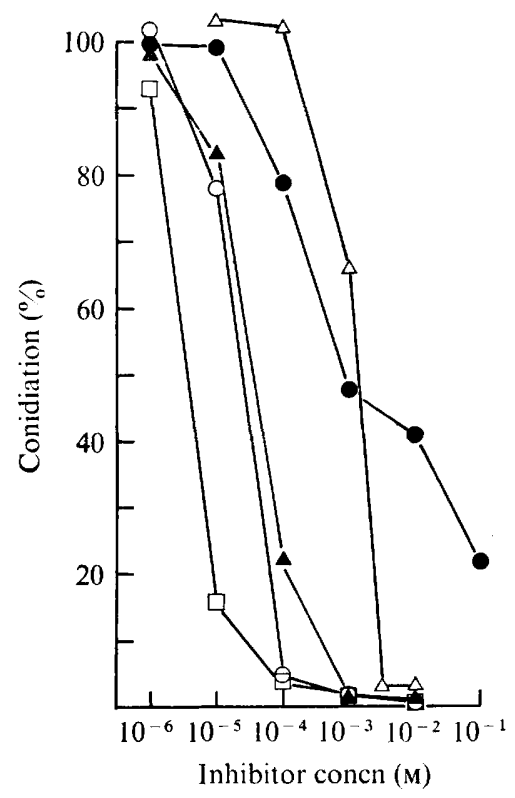

Fig. I. Effect of inhibitors on light-induced conidiation in B. cinerea: $\bigcirc$, FdUrd;, 6 -azauridine; $\triangle$, miracil D; $\Delta, 5$-fluorouracil; $\square$, cycloheximide. Cultures on filter paper were incubated in the dark for 3 days before application of inhibitors and irradiation for $12 \mathrm{~h}$. Conidium production was assayed $24 \mathrm{~h}$ after the end of photoinduction, and is expressed as a percentage of that in cultures without added inhibitor. Each point is the mean of counts of six cultures (ten counts per culture) from two separate experiments.

required concentration of inhibitor. The transfer was carried out under green safe light (Kodak green filter no. I2) and, unless otherwise stated, just before black light irradiation.

Radioisotope incorporation. Isotope pairs, $\left[\mathrm{U}_{-}^{14} \mathrm{C}\right]$ uridine $\left(522 \mathrm{mCi} \mathrm{mmol}^{-1}\right)$ and $\mathrm{L}-\left[\mathrm{G}-{ }^{3} \mathrm{H}\right] l e u c i n e(250 \mathrm{mCi}$ mmol $\left.{ }^{-1}\right)$, [U-14 $\left.\mathrm{C}\right]$ uridine and $\left[6-{ }^{3} \mathrm{H}\right]$ thymidine $\left(26 \mathrm{Ci} \mathrm{mmol}^{-1}\right)$, were added to media with or without inhibitor to give activities of $0 \cdot 1 \mu \mathrm{Ci}^{14} \mathrm{C}$ and $\mathrm{I} \mu \mathrm{Ci}^{3} \mathrm{H}$ per ml medium. Incorporation of radioisotope was stopped at various times by removing the filter paper circle from the pad, rapidly washing (three times with cold I mM- $\mathrm{MgCl}_{2}$, and three times with cold, distilled $\mathrm{H}_{2} \mathrm{O}$ ) on a Buchner funnel, and then freezing in liquid nitrogen.

The mycelia on the filter paper were then fixed for $2 \mathrm{~h}$ in cold ethanol/acetic acid $(3: \mathrm{I}, \mathrm{v} / \mathrm{v})$ with one change of fixative. Soluble metabolites were removed by immersing into cold perchloric acid $(0 \cdot 25 \mathrm{M})$ for $30 \mathrm{~min}$ and then rinsing with cold $70 \%(\mathrm{v} / \mathrm{v})$ ethanol. The filter papers were finally air-dried, and cut into strips of $2 \times 1 \mathrm{~cm}$ for counting the radioactivity.

Counting of radioactivity. This was carried out using an Intertechnique $\mathrm{SL}_{3}$ o liquid scintillation spectrometer. Each filter paper strip was placed in a scintillation vial containing $12 \mathrm{ml}$ of scintillation fluid $(4 \mathrm{~g}$ 2,5-diphenyloxazole and $100 \mathrm{mg}$ I,4-bis[2(5-phenyloxazolyl)]benzene in I 1 toluene). The counts were corrected for cross channel contribution.

Chemicals. 5-Fluoro-2-deoxyuridine (FdUrd) was purchased from Hoffmann La Roche; 6-azauridine, 5 -fluorouracil, cycloheximide, actinomycin D, puromycin, PPO and POPOP were from Sigma; miracil D (lucanthone) was a gift from Burroughs Wellcome \& Co. Radioactive chemicals were bought from The Radiochemical Centre, Amersham.

\section{RESULTS}

\section{Effect of inhibitors on conidiation}

FdUrd, 6-azauridine, miracil D, 5-fluorouracil and cycloheximide inhibited photoinduced conidiation in $B$. cinerea at various concentrations (Fig. I). Cycloheximide, at $\mathrm{IO}^{-5} \mathrm{M}$, gave more than $80 \%$ inhibition, and complete inhibition was obtained at $\mathrm{IO}^{-4} \mathrm{M}$. With FdUrd and fluorouracil, almost complete suppression was obtained at $10^{-4} \mathrm{M}$ and $10^{-3} \mathrm{M}$ respec- 
Table I. Time of application of inhibitor and the effect on photoinduced conidiation in B. cinerea

Conidiation is expressed as a percentage of the number of conidia produced in photoinduced cultures in the absence of inhibitor; each result is the mean of six cultures from two separate experiments.

\begin{tabular}{|c|c|c|}
\hline \multirow[b]{2}{*}{ Inhibitor } & \multicolumn{2}{|c|}{$\begin{array}{l}\% \text { conidiation after } \\
\text { application of inhibitor: }\end{array}$} \\
\hline & $\begin{array}{c}\text { Before } \\
\text { photoinduction } \\
(\mathrm{o} \mathrm{h})\end{array}$ & $\begin{array}{l}\text { After } \\
\text { photoinduction } \\
(12 \mathrm{~h})\end{array}$ \\
\hline 5-Fluorouracil $\left(\mathrm{IO}^{-3} \mathrm{M}\right)$ & $\mathrm{I} \cdot 6$ & $20 \cdot 0$ \\
\hline Cycloheximide $\left(\mathrm{IO}^{-4} \mathrm{M}\right)$ & $3 \cdot 2$ & $42 \cdot I$ \\
\hline 5-Fluoro-2-deoxyuridine $\left(\mathrm{IO}^{-4} \mathrm{M}\right)$ & $5 \cdot 2$ & $45 \cdot 2$ \\
\hline 6-Azauridine $\left(\mathrm{IO}^{-1} \mathrm{M}\right)$ & $30 \cdot 2$ & $53 \cdot 0$ \\
\hline Miracil D $\left(5 \times 10^{-3} \mathrm{M}\right)$ & $3 \cdot 4$ & $23 \cdot 5$ \\
\hline
\end{tabular}

Table 2. Effect of 5-fluoro-2-deoxyuridine and miracil $D$ on the incorporation of $\left[{ }^{14} \mathrm{C}\right]$ uridine and $\left[{ }^{3} \mathrm{H}\right]$ thymidine into perchloric acidlethanol-insoluble material of $B$. cinerea during photoinduction

The radioactive chemicals and inhibitors were added immediately before photoinduction, and incorporation was stopped after $3 \mathrm{~h}$ and $6 \mathrm{~h}$. FdUrd and miracil D were added at $10^{-4} \mathrm{M}$ and $5 \times 10^{-3} \mathrm{M}$ respectively. Incorporation is expressed as \% inhibition compared with control cultures (without added inhibitors); each result is the mean of six cultures from two independent experiments. The c.p.m. in each culture were calculated from the mean of counts of five filter paper strips.

\begin{tabular}{|c|c|c|c|c|}
\hline \multirow{3}{*}{$\begin{array}{l}\text { Duration of } \\
\text { labelling (h) }\end{array}$} & \multicolumn{4}{|c|}{ Inhibition of incorporation $(\%)$} \\
\hline & \multicolumn{2}{|c|}{$\left[{ }^{14} \mathrm{C}\right]$ Uridine } & \multicolumn{2}{|c|}{$\left[{ }^{3} \mathrm{H}\right]$ Thymidine } \\
\hline & + FdUrd & + Miracil D & + FdUrd & + Miracil D \\
\hline 3 & $59 \cdot 8$ & 93.0 & $55 \cdot 6$ & $90 \cdot 6$ \\
\hline 6 & $57 \cdot 2$ & 94.9 & $58 \cdot 6$ & $94 \cdot 9$ \\
\hline
\end{tabular}

tively. Relatively high concentrations of 6-azauridine and miracil D were required for inhibition of conidiation. Even $0 \cdot$ I M-azauridine did not completely suppress conidiation.

Actinomycin D and puromycin were also tested. At $10^{-4}$ to $10^{-6} \mathrm{M}$, they did not inhibit conidiation in B. cinerea.

\section{Application of inhibitor just before and after photoinduction}

In the above experiments, inhibitors were applied just before photoinduction. It was of interest to see whether conidiation could still be suppressed if the inhibitors were applied immediately after the photoinduction period. After the dark incubation period, cultures were transferred to fresh filter paper pads soaked with media either containing the inhibitors (these were the cultures subjected to inhibitors during the photoinduction period and thereafter) or without inhibitors. Both sets of cultures were irradiated, and then those without added inhibitors were placed on filter paper pads with inhibitors (these were the cultures subjected to inhibitors immediately after photoinduction). Conidia produced were counted at the usual time. The results showed that inhibition of conidiation was more pronounced when the inhibitors were added just before the photoinduction period (Table I). Some $45 \%$ conidiation still occurred if FdUrd and cycloheximide were added after photoinduction. Fluorouracil and miracil D caused about $80 \%$ inhibition when applied after the photoinduction period. It is not clear why the latter two inhibitors caused greater inhibition than the other three when applied after photoinduction. 
Table 3. Effect of 5-fluorouracil and cycloheximide on the incorporation of $\left[{ }^{14} \mathrm{C}\right]$ uridine and $\left[{ }^{3} \mathrm{H}\right]$ leucine into perchloric acid/ethanol-insoluble material of $B$. cinerea during photoinduction

Fluorouracil and cycloheximide were added at $10^{-3} \mathrm{M}$ and $10^{-4} \mathrm{M}$ respectively. For other details, see legend to Table 2.

\begin{tabular}{|c|c|c|c|c|}
\hline \multirow{3}{*}{$\begin{array}{l}\text { Duration of } \\
\text { labelling }(\mathrm{h})\end{array}$} & \multicolumn{4}{|c|}{ Inhibition of incorporation $(\%)$} \\
\hline & {$\left[{ }^{14} \mathrm{C}\right]$} & Jridine & {$\left[{ }^{3} \mathrm{H}\right]$} & eucine \\
\hline & + Fluorouracil & + Cycloheximide & + Fluorouracil & + Cycloheximide \\
\hline $\begin{array}{l}3 \\
6\end{array}$ & $\begin{array}{l}27 \cdot 2 \\
47 \cdot 1\end{array}$ & $\begin{array}{l}35 \cdot 6 \\
60 \cdot 3\end{array}$ & $\begin{array}{r}I \cdot 8 \\
3 I \cdot 4\end{array}$ & $\begin{array}{l}55 \cdot 4 \\
72 \cdot 9\end{array}$ \\
\hline
\end{tabular}

Incorporation of radioactive precursors of nucleic acids and proteins during photoinduction

To determine whether the inhibitors were affecting the synthesis of nucleic acids and proteins, radioactive precursors, viz. $\left[{ }^{14} \mathrm{C}\right]$ uridine, $\left[{ }^{3} \mathrm{H}\right]$ thymidine and $\left[{ }^{3} \mathrm{H}\right]$ leucine, were added to the cultures just before irradiation.

In the presence of FdUrd $\left(\mathrm{IO}^{-4} \mathrm{M}\right)$ and miracil $\mathrm{D}\left(5 \times \mathrm{IO}^{-3} \mathrm{M}\right)$, incorporation of both uridine and thymidine into perchloric acid/ethanol-insoluble material was considerably reduced (Table 2). More pronounced inhibition of incorporation was obtained using miracil D. Fluorouracil $\left(\mathrm{IO}^{-3} \mathrm{M}\right)$ and cycloheximide $\left(\mathrm{IO}^{-4} \mathrm{M}\right)$ inhibited both uridine and leucine incorporation (Table 3). Greater inhibition of incorporation was obtained using cycloheximide.

\section{DISCUSSION}

The results obtained in this study showed that light-induced conidiation in $B$. cinerea was inhibited by various inhibitors of nucleic acid and protein synthesis. Cycloheximide, a well known inhibitor of protein synthesis, was the most potent inhibitor. FdUrd, an inhibitor of DNA precursor synthesis, and fluorouracil, an inhibitor of both nucleic acid synthesis and protein synthesis, were also very effective. Actinomycin D and puromycin, at the concentrations tested, were the only two that did not affect conidiation. Experiments have also shown that these inhibitors, at $\mathrm{IO}^{-4} \mathrm{M}$, did not affect the incorporation of radioactive precursors into trichloroacetic acid-precipitable material (unpublished observations). The ineffectiveness of these inhibitors may be due to the fungus being impermeable to the compounds.

The incorporation of precursors of nucleic acids and proteins during the photoinduction period was substantially reduced in the presence of FdUrd, miracil D, fluorouracil, and cycloheximide. This suggests that the synthesis of nucleic acids and proteins was inhibited by these compounds. To what extent DNA synthesis is affected cannot be ascertained from the experiments because it was found that thymidine (which was added to the medium to measure DNA synthesis) is not specifically incorporated into DNA; it is also incorporated into RNA. That DNA synthesis is affected can be inferred from the results of suppression of conidiation by FdUrd. This paper thus shows that light-induced conidiation in $B$. cinerea requires synthesis of both types of nucleic acid, and proteins.

This work was carried out during the tenure of an Irish Department of Education postdoctoral research fellowship. 


\section{REFERENCES}

CARlile, M. J. (1965). The photobiology of fungi. Annual Review of Plant Physiology 16, 175-202.

Carlile, M. J. (I970). The photoresponses of fungi. In Photobiology of Microorganisms, pp. 309-344. Edited by P. Halldal. London and New York: Wiley-Interscience.

Gressel, J. \& GaLUN, E. (1967). Morphogenesis in Trichoderma: photoinduction and RNA. Developmental Biology 15, 575-598.

LEACH, C. M. (I97I). A practical guide to the effects of visible and ultraviolet light on fungi. Methods in Microbiology 4, 609-664.

Mummery, R. S. \& Valadon, L. R. G. (1973). Effect of certain nucleic acid and protein inhibitors on carotenogenesis in Verticillium agaricinum. Physiologia plantarum 28, 254-257.

RAU, W. (1967). Untersuchungen über die lichtabhängige Carotinoidsynthese. II. Ersatz der Lichtinduktion durch Mercuribenzoat. Planta 74, 263-277.

Rau, W., Lindemann, I. \& RaU-Hund, A. (1968). Untersuchungen über die lichtabhängige Caro- tinoidsynthese. III. Die Farbstoffbildung von Neurospora crassa in Submerskultur. Planta 8o, 309-316.

STALLINGS, F. O. (1970). The physiological control of light induced conidiation in Aspergillus ornatus. Ph.D. thesis, University of Wisconsin, U.S.A.

TAN, K. K. (1976). Light-induced synchronous conidiation in the fungus Botrytis cinerea. Journal of General Microbiology 93, 278-282.

TAN, K. K. \& EPTON, H. A.S. (1973). Effect of light on the growth and sporulation of Botrytis cinerea. Transactions of the British Mycological Society 6r, I45-157.

TotTen, R. E. \& Howe, H. B., Jr (197I). Temperature-dependent actinomycin $\mathrm{D}$ effect on RNA synthesis during synchronous development in Neurospora crassa. Biochemical Genetics 5, $52 \mathrm{I}-$ 532.

UREY, J. C. (1971). Enzyme patterns and protein synthesis during synchronous conidiation in Neurospora crassa. Developmental Biology 26, I7-27. 